Egyptian J. Anim. Prod. 35, Suppl. Issue Dec. (1998):33-45.

\title{
INFLUENCE OF HOUSING PHYSICAL PROPERTIES ON PHYSIOLOGICAL PERFORMANCE OF SUCKLING FRIESIAN CALVES
}

\author{
G. Ashour ${ }^{1}$, M.M. Shafie ${ }^{1}$, S.A. Fawzy ${ }^{2}$ and M. S.Sayah ${ }^{2}$ \\ 1- Department of Animal Production, Faculty of Agriculture, Cairo University, Giza, \\ Egypt, 2-Animal Production Research Institute, Dokki, Egypt
}

\section{SUMMARY}

Twenty four suckling Friesian calves were used to study their physiological responses as affected by housing in asbestos roofed stable during winter and summer seasons in the Nile Delta, Egypt. The calves average age and weight were ranged between 4 to 5 weeks and 39 to $46 \mathrm{Kg}$, respectively. The studied parameters were, climatic conditions indoors and outdoors, thermal properties of building components (roof, walls and floor) alongside with physiological responses; rectal temperature, both white and black skin and hair temperatures, respiration rate, hemoglobin and hematocrit values, leukocyte types and plasma $T_{4}$ and $T_{3}$ concentrations. Climatic conditions, thermal and respiratory responses were recorded, simultaneously, two times a day at 08:00 $\mathrm{h}$ and $14: 00 \mathrm{~h}$ during two days at weekly intervals. While blood samples were taken at 08:00 $\mathrm{h}$ and 14:00 $\mathrm{h}$ a day at weekly intervals, moreover, the physical thermal properties of building components were tested at four times (06:00, 12:00, $15: 00$ and $22: 00$ hs) on the same day. The housing components of the stable showed seasonal and diurnal effects on all the physiological responses of calves. There were highly significant correlations between the calves thermal reactions parameters and respiration rate with air temperature and relative humidity and between each other.

It is concluded that the asbestos roofed stable is characterized by a wider diurnal fhythm. Thus, it could be suggested that the colder walls and roof at night and early morning (22:00 and 06:00 hs) act as heat sinks, which facilitates heat dissipation from animals' body that was accumulated at midday time. This suggestion needs further studies and consideration within designed housing models.

Keywords: Friesian suckling calves, housing, physiological performance, seasonal and diurnal effects

Issued by The Egyptian Society of Animal Production 


\section{INTRODUCTION}

The thermal environment in animal houses is important because of its direct thermal effects on the metabolic rate and consequently the efficiency of production by the livestock, and its indirect effects on animal's health and welfare. It is, therefore, important to understand the thermal interactions between livestock and their building microclimates, also between the building microclimate and the weather outside, whether the livestock are housed for climatic or management reasons. Poor building design and unsuitable microclimates can result in thermal stress on the livestock, with consequent productive losses and risks to welfare. Poor ventilation may also increase the risks to the livestock for disease and damaging concentrations of atmospheric contaminants, particularly ammonia (Charles, 1981 and Clark and Cena, 1981). The interaction between the physical thermal exchange and the physiology of the animals is a complex, but must be understood to a reasonable degree in order to fulfill proper environments in which animals can be housed to meet both production and welfare requirements (Clark and McArthur, 1994).

Any calf housing and management system must provide certain basic requirements to ensure the health, comfort and good growth of the calves confined therein. The most important basic requirements are, fresh air, a dry bed and freedom from stress (Milne, 1983 and Webster, 1984). Calf housing should meet the health and behavioural needs of the animals, the major requirements can be translated into specifications for climate, space, allowances, ventilation and shelter or pen design (Lawrence, 1994). Hahn (1985) stated that the aspects of partially or fully enclosed livestock structures must be considered in reduction of thermal radiation, proper natural air velocity as well as sanitation. There are no guidelines for evaluating the benefits to animal performance of open-walled vs. partially or fully closed shelters. With the optimum thermal capacity, the inside temperature will not only be moderated and relatively constant but will reach its minimum during midday. Floor type is critical to thermal control, physical comfort, health and security. Webster (1981) reported that calves tend to spend a large time laying down on straw than on other surfaces, thus conserve energy by reducing contact with the active thermal conductivity in the other surfaces. Thermorespiratory responses and hematological changes in reaction to environmental conditions are the most sensitive indices and indicators of comfortable case of animals.

The present work is a preliminary trial executed to study the effects of diurnal and seasonal changes on physiological responses of suckling Friesian calves as affected by physical thermo-condition in a closed stable roofed by asbestos sheets. It also aimed to assess the physical properties of the building and its impacts on the calves' response. Thermal balance between the stable inside microclimate and the outdoors climate was also considered. 


\section{MATERIALS AND METHODS}

This study was carried out at the Animal Production Research Institute farm at Sakha Experimental Station, located in the northern part of the Nile Delta region. This work was executed in a closed stable during winter season (January and February) and summer season (July and August).

\section{Experimental animals}

Twenty four healthy suckling Friesian calves were selected randomly and used in this study. Fourteen sucklings averaged 4 weeks of age and $39 \mathrm{Kg}$ body weight were used in winter, another, ten sucklings averged 5 weeks of age and $46 \mathrm{Kg}$ body weight were used in summer.

\section{Housing and feeding}

The calves were individually housed in cubicles within the stable as shown in Figure (1). The stable walls and cubicle partitions were built of bricks and cement. The roof was made of corrugated asbestos sheets at the height of $5 \mathrm{~m}$ in the middle and $3.5 \mathrm{~m}$ at both sides and the floor was made of concrete. Ventilation is acquired by $1 \mathrm{~m}$ horizontal openings throughout the walls at 2.0 to $3.0 \mathrm{~m}$ above the ground. The experimental area in the stable was separated by a complete wall-like rice straw stacks. Milk was offered to the calves twice a day, at $07: 00 \mathrm{~h}$ and 17:00 $\mathrm{h}$, supplemented with concentrate ration and hay according to the calves age and to the farm routine.

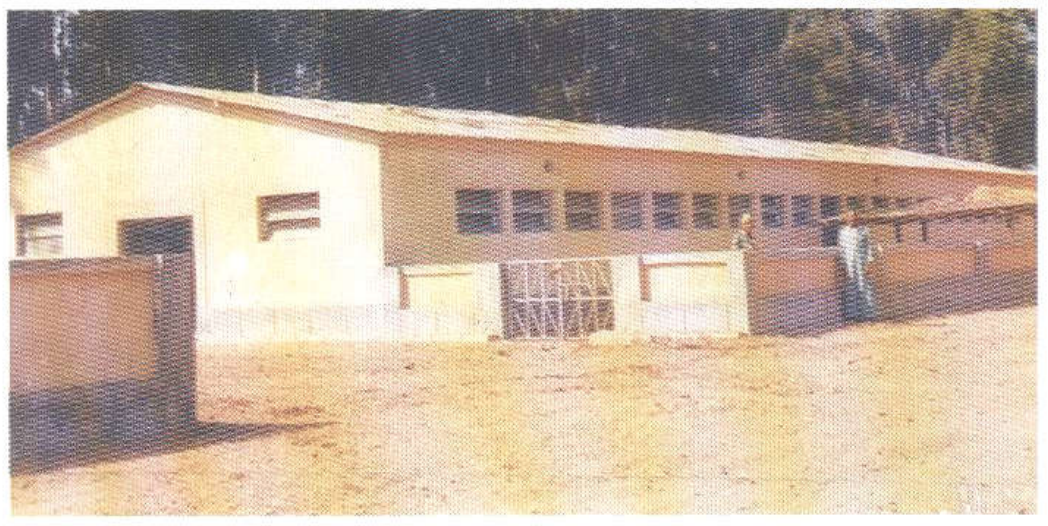

Fig. 1. Housing type (close - stable) for suckling calves 
Technical procedure

Air temperature and relative humidity were recorded indoors and outdoors two times a day, at 08:00 h and 14:00 h, in two days at weekly intervals simultaneously with measuring the physiological responses. Meanwhile, blood samples were taken at $08: 00 \mathrm{~h}$ and 14:00 h in one day at weekly intervals. Internal and external temperatures of walls and roof alongside that of the floor were determined by using infrared thermometer four times a day at 06:00h, 12:00h, 15:00h and 22:00h. Rectal temperature, both white and black skin and hair temperatures were obtained by clinical and digital thermometers, respectively. Respiratory rate was determined by counting the flank's movements/min. Blood samples were collected from the Jugular vein in tubes provided with EDTA as an anticoagulant from 6 calves in winter and 5 calves in summer. Fresh blood samples were used to determine each of hemoglobin concentration ( $\mathrm{g} / \mathrm{dl})$ by kits of Egyptian American Company, hematocrit value $(\%)$ by a microhematocrit centrifuge, 12000 r.p.m. for 3 min. and differential leukocytes count by using stained blood films by Leishman's stain. Clear plasma was separated to determine the concentration of $T_{3}$ and $T_{4}$ hormones by using RIA techniques of Diagonestic Product Corporation (DPC, USA). The physiological responses were carried out during two days at weekly intervals. The hematological tests as well as blood sampling for $T_{3}$ and $T_{4}$ assay were carried out during a day at weekly intervals.

Relevant statistical analysis of data was carried out applying SAS package (1990). Correlation coefficients among the variables were estimated according to Sendecor (1982). Also, Duncan test (1955) was done to determine the degree of significance in differences between the means.

\section{RESULTS AND DISCUSSION}

\section{1- Climatic conditions}

There were great seasonal and diurnal variations in the environmental conditions indoors and outdoors (Table 1).

Table 1. Seasonal and diurnal outdoors and indoors climatic conditions in asbestos roofed stable during winter and summer seasons

\begin{tabular}{lcccc}
\hline Items & \multicolumn{2}{c}{ Winter } & \multicolumn{2}{c}{ Summer } \\
\cline { 2 - 5 } & $08: 00 \mathrm{~h}$ & $14: 00 \mathrm{~h}$ & $08: 00 \mathrm{~h}$ & $14: 00 \mathrm{~h}$ \\
\hline Climatic conditions: & & & & \\
\hline OAT ${ }^{\circ} \mathrm{C}$ & $11.8^{\mathrm{d}}$ & $18.9^{\mathrm{c}}$ & $24.3^{\mathrm{b}}$ & $34.4^{\mathrm{a}}$ \\
IAT ${ }^{\circ} \mathrm{C}$ & $12.3^{\mathrm{d}}$ & $19.9^{\mathrm{c}}$ & $25.0^{\mathrm{b}}$ & $33.8^{\mathrm{a}}$ \\
ORH \% $^{\text {IRH \% }}$ & $80.2^{\mathrm{b}}$ & $60.2^{\mathrm{ab}}$ & $85.4^{\mathrm{c}}$ & $55.3^{\mathrm{cd}}$ \\
\hline
\end{tabular}

Mean values with the same superscript letters are not significantly different. 
Egyptian J. Anim. Prod. (1998)

Summer afternoon showed the highest air temperature (AT) and the lowest relative humidity $(\mathrm{RH})$. Summer morning showed the highest $\mathrm{RH}$, while the winter morning showed the lowest AT. The averages of both indoors air temperature (IAT) and indoors relative humidity $(\mathrm{IRH})$ were higher than those of outdoors (OAT and ORH) except only at summer afternoon, where the IAT was lower than OAT. However, the differences between indoors and outdoors in both AT and RH were insignificant when compared at their respective times.

\section{2- Physical properties of the building}

Winter and summer data revealed that the lowest values of internal and external temperatures of walls and roof, floor and IAT were at 06:00 h, followed by great increase at 12:00 h and 15:00 h, with a clear drop at 22:00 h. This trend of fluctuation was more apparent in roof temperature, especially in summer, than in IAT, being the least in floor and wall temperatures (Table 2). Wall temperatures showed the highest values at 15:00h while the roof temperature showed the highest values at 12:00 h in both winter and summer seasons. These data indicate that asbestos roof was affected by radiant heat earlier than walls followed by floor and IAT. Concerning walls sides, the southern wall showed higher external temperature, at 12:00 h and 15:00 h, both in winter $\left(20^{\circ} \mathrm{C}\right.$ and $\left.23^{\circ} \mathrm{C}\right)$ and in summer $\left(47^{\circ} \mathrm{C}\right.$ and $\left.46^{\circ} \mathrm{C}\right)$, respectively than the other sides, this is due to exposure of this wall to direct solar radiation at these day times. However, this was not reflected directly on the internal temperature of this wall, which was almost similar to those of the other walls.

Table 2. Seasonal and diurnal temperatures $\left({ }^{\circ} \mathrm{C}\right)$ of walls, roof, floor (internal, Int and external ,Ext surfaces) and internal air temperature (IAT) in asbestos roofed stable

\begin{tabular}{cllllllll}
\hline Items & \multicolumn{4}{c}{ Winter } & \multicolumn{5}{c}{ Summer } \\
\cline { 2 - 9 } & $06: 00 \mathrm{~h}$ & $12: 00 \mathrm{~h}$ & $15: 00 \mathrm{~h}$ & $22: 00 \mathrm{~h}$ & $06: 00 \mathrm{~h}$ & $12: 00 \mathrm{~h}$ & $15: 00 \mathrm{~h}$ & $22: 00 \mathrm{~h}$ \\
\hline $\begin{array}{c}\text { Int. } \\
\text { Walls }\end{array}$ & 9.8 & 12.5 & 13.5 & 11.5 & 22.5 & 27.3 & 27.5 & 24.5 \\
$\quad$ Ext. & 6.3 & 16.0 & 17.5 & 9.0 & 19.5 & 34.3 & 36.3 & 23.0 \\
\hline $\begin{array}{c}\text { Int. } \\
\text { Roof } \\
\text { Ext. }\end{array}$ & 5.0 & 23.0 & 20.0 & 7.0 & 16.0 & 51.0 & 35.0 & 19.0 \\
\hline Floor & 11 & 15 & 17 & 12 & 22 & 25 & 23 & 23 \\
\hline IAT & 12 & 21 & 22 & 12 & 21 & 32 & 32 & 24 \\
\hline
\end{tabular}

The seasonal variations in building components temperature were more pronounced at 12:00 h and 15:00 h, but were less at 06:00 h and 22:00 h. The seasonal differences were the highest at $12: 00 \mathrm{~h}$ in roof temperature being $29.5{ }^{\circ} \mathrm{C}$ and in wall temperature being $16.6^{\circ} \mathrm{C}$. The highest differences in floor and IAT were observed at $22: 00 \mathrm{~h}$ being 11.0 and $12.0^{\circ} \mathrm{C}$, respectively. The temperatures of the building components decreased greatly at 22:00 h, and this diurnal change was more clear in roof temperature in both winter and 
summer. These decreases in roof temperature from the average of noon plus afternoon $(12: 00 \mathrm{~h}+15: 00 \mathrm{~h} / 2)$ to that at $22: 00 \mathrm{~h}$ in internal and external temperatures were 14.5 and $21.0^{\circ} \mathrm{C}$ in winter and 24.0 and $32.5^{\circ} \mathrm{C}$ in summer, respectively. The corresponding values in wall temperatures were 1.5 and $7.8^{\circ} \mathrm{C}$ in winter and 2.9 and $12.3^{\circ} \mathrm{C}$ in summer, respectively. Meanwhile, the diurnal changes values were oniy 4.0 and $1.0^{\circ} \mathrm{C}$ in floor temperature in winter and summer, respectively. The indoors air temperature (IAT) showed slight diurnal changes being 9.5 and $8.0^{\circ} \mathrm{C}$ in winter and summer, respectively (Table 2).

\section{3- Thermal responses of animals}

Rectal temperature (RT) of the calves was the highest $(P<0.01)$ at $14: 00 \mathrm{~h}$ in summer, while it was the lowest at 08:00 h in winter (Table 3). The diurnal changes in RT were more obvious than the seasonal changes, although the differences were very slight, did not exceed $0.4^{\circ} \mathrm{C}$. The present diurnal and seasonal changes in RT are in agreement with results by Badreldin et al. (1951), Shafie and El-Sheikh Aly (1970) and Kobeisy (1983).

Table 3. Physiological responses of suckling Friesian calves in asbestos roofed stable during winter and summer seasons

\begin{tabular}{|c|c|c|c|c|}
\hline \multirow[t]{2}{*}{ Iterns } & \multicolumn{2}{|c|}{ Winter } & \multicolumn{2}{|c|}{ Summer } \\
\hline & $08: 00 h$ & $14: 00 \mathrm{~h}$ & 08:00h & 14:00h \\
\hline \multicolumn{5}{|l|}{ Thermal responses: } \\
\hline$R T{ }^{\circ} \mathrm{C}$ & $38.7^{e} \pm 0.1$ & $39.1^{b c d} \pm 0.1$ & $39.0^{\text {cd }} \pm 0.1$ & $39.3^{b} \pm 0.1$ \\
\hline $\mathrm{BST}{ }^{\circ} \mathrm{C}$ & $34.4^{\dagger} \pm 0.1$ & $35.2^{c d} \pm 0.1$ & $36.0^{b} \pm 0.1$ & $36.8^{\mathrm{a}} \pm 0.1$ \\
\hline WST ${ }^{\circ} \mathrm{C}$ & $33.6^{d} \pm 0.1$ & $34.6^{c} \pm 0.1$ & $35.7^{6} \pm 0.1$ & $36.5^{a} \pm 0.1$ \\
\hline $\mathrm{BHT}{ }^{\circ} \mathrm{C}$ & $31.3^{e} \pm 0.1$ & $32.1^{c d} \pm 0.1$ & $33.3^{\circ} \pm 0.1$ & $35.0^{a} \pm 0.1$ \\
\hline WHT ${ }^{\circ} \mathrm{C}$ & $30.9^{d} \pm 0.1$ & $31.8^{c} \pm 0.1$ & $33.2^{b} \pm 0.1$ & $34.8^{\mathrm{a}} \pm 0.1$ \\
\hline \multicolumn{5}{|l|}{ Respiratory response: } \\
\hline RR (breath/min.) & $31.3^{h i} \pm 0.8$ & $38.8^{f g} \pm 1.1$ & $52.8^{\mathrm{e}} \pm 1.4$ & $66.0^{\mathrm{cd}} \pm 1.5$ \\
\hline \multicolumn{5}{|l|}{ Hematological responses: } \\
\hline $\mathrm{Hb}(\mathrm{g} / \mathrm{dl})$ & $12.3^{a} \pm 0.2$ & $12.6^{a} \pm 0.1$ & $10.4^{b} \pm 0.3$ & $10.3^{b} \pm 0.3$ \\
\hline $\mathrm{Ht}(\%)$ & $34.8^{\mathrm{a}} \pm 0.3$ & $34.8^{a} \pm 0.4$ & $32.2^{b c} \pm 1.0$ & $29.9^{c} \pm 0.7$ \\
\hline Lymophocytes (\%) & $67.6 \pm 0.9$ & $68.3^{\mathrm{bc}} \pm 0.6$ & $57.9^{f} \pm 1.4$ & $59.0^{\text {ef }} \pm 1.3$ \\
\hline Neutrophils (\%) & $27.1 \pm 0.6$ & $25.6^{\mathrm{de}} \pm 0.6$ & $32.7^{a b} \pm 1.1$ & $31.9^{\mathrm{ab}} \pm 1.2$ \\
\hline Eosinophils (\%) & $2.7^{d e} \pm 0.2$ & $3.1^{\text {cde }} \pm 0.2$ & $4.6^{\mathrm{ab}} \pm 0.4$ & $5.0^{\mathrm{a}} \pm 0.4$ \\
\hline Basophils $\quad(\%)$ & $0.1^{a b} \pm 0.1$ & $0.2^{\mathrm{ab}} \pm 0.1$ & $0.2^{\mathrm{ab}} \pm 0.1$ & $0.1^{\mathrm{ab}} \pm 0.1$ \\
\hline Monocytes $(\%)$ & $2.8^{\text {cdef }} \pm 0.2$ & $2.8^{\text {cdef }} \pm 0.2$ & $4.6^{\mathrm{a}} \pm 0.3$ & $4.2^{\mathrm{ab}} \pm 0.3$ \\
\hline \multicolumn{5}{|l|}{ Thyroid hormones } \\
\hline $\mathrm{T}_{4}(\mu \mathrm{g} / \mathrm{d})$ & $3.9^{d} \pm 0.4$ & $4.2^{\mathrm{cd}} \pm 0.4$ & $4.5^{\mathrm{cd}} \pm 0.2$ & $4.6^{\text {cd }} \pm 0.3$ \\
\hline$T_{3}(\mathrm{ng} / \mathrm{dl})$ & $108.2^{a} \pm 16.0$ & $122.6^{a} \pm 17.3$ & $106.9^{\mathrm{a}} \pm 7.5$ & $112.9^{\mathrm{a}} \pm 5.9$ \\
\hline $\mathrm{T}_{4} / \mathrm{T}_{3}$ ratio & 36.0 & 34.3 & 42.1 & 40.7 \\
\hline
\end{tabular}

There were highly significant diurnal and seasonal variations in black and white skin temperatures (BST,WST) and in black and white hair temperatures 


\section{Respiratory response}

It can be seen from Table (3) that the greatly affected and most sensitive reaction to both diurnal and seasonal changes in AT was respiration rate (RR). It was highly associated with AT, and there were highly significant diurnal and seasonal variations in RR being higher in summer particularly in the afternoon. The climatic seasonal changes in AT (summer - winter) produced greater change in $R R$ than the diurnal changes (14:00-08:00hs). The calves showed faster breathing in summer than in winter by 21.5 and $27.2 / \mathrm{min}$ at $08: 00$ and $14: 00 \mathrm{hs}$, respectively. The diurnal changes caused 7.5 and $13.2 \mathrm{breath} / \mathrm{min}$ more at 14:00 h than that at 08:00h. The greater RR confirmed that calves at this age depend mainly in maintaining their heat balance on the evaporative cooling through the respiratory surface rather than from skin surface. Since, the heat loss under hot conditions by physical means (conduction, convection and radiation) were not sufficient or negative. This respiratory mishap seems to be, mainiy, a product of the negative temperature gradient from the roof to the calves surfaces, as reported above. A cool inner roof surface is apt to prevent, or at least reduce, this bad result. Roofing material, structure, establishment, insulation...etc are of great significance and need extensive studies.

The correlation coefficients of thermal and respiratory responses were positive and highly significant with AT, but were negative and highly significant with $\mathrm{RH}$. Also, there were positive correlations among the physiological responses (Table 5).

Table 5. Correlation coefficients of air temperature (AT) and relative humidity

$(\mathrm{RH})$ in winter and summer with physiological performance of suckling

Friesian calves in asbestos roofed stable and among physiological

thermal and respiration responses

\begin{tabular}{llllllll}
\hline ltems & AT & RH & RR & RT & WST & BST & WHT \\
\hline RH & $-0.46^{* *}$ & & & & & & \\
RR & $0.76^{* *}$ & $-0.26^{* *}$ & & & & & \\
RT & $0.39^{* * *}$ & $-0.32^{* *}$ & $0.14^{* *}$ & & & & \\
WST & $0.29^{* *}$ & $-0.40^{* *}$ & $0.22^{* *}$ & $0.19^{* *}$ & & & \\
BST & $0.82^{* *}$ & $-0.89^{* *}$ & $0.68^{* *}$ & $0.43^{* *}$ & $0.19^{* *}$ & & \\
WHT & $0.35^{* *}$ & $-0.24^{* *}$ & $0.26^{* *}$ & $0.21^{* *}$ & $0.99^{* *}$ & $0.24^{* *}$ & \\
BHT & $0.90^{* *}$ & $-0.36^{* *}$ & $0.72^{* *}$ & $0.39^{* *}$ & $0.24^{* *}$ & $0.85^{* *}$ & $0.32^{* *}$ \\
\hline
\end{tabular}

${ }^{* *} P<0.01$

\section{5- Hematological responses}

There were negative relationships between both the hemoglobin $(\mathrm{Hb})$ concentration and hematocrit value (Ht) with AT as evidenced by both seasonal and diurnal variations (Table 3 ). Winter values of $\mathrm{Hb}$ were greater than summer values by 1.9 and $2.3 \mathrm{~g} / \mathrm{dl}$ at $08: 00$ and $14: 00 \mathrm{hs}$, respectively, the corresponding values of $\mathrm{Ht}$ were 2.6 and $4.9 \%$, respectively. Summer afternoon values of $\mathrm{Hb}$ and $\mathrm{Ht}$ were lower than morning values, but the 
difference was insignificant. There was no difference in $\mathrm{Ht}$ between day times in winter and the difference in $\mathrm{Hb}$ values was very minor. These findings are in agreement with those of Kotby et al. (1987) in Friesian cows kept under asbestos and linen textile sheds and with those of Ashour (1990) in outdoors studies.

The lower value of $\mathrm{Hb}$ and $\mathrm{Ht}$ observed in this study under high AT could be attributed to the added heat stress by heat radiation from the roof and walls onto the animal body. Hemodilution may be another factor reducing both $\mathrm{Hb}$ and $\mathrm{Ht}$ concentrations.

\section{6- Leukocyte types}

The percentages of neutrophils, eosinophils and monocytes were lower and the percentage of lymphocytes was higher $(P<0.01)$ in winter than in summer (Table 3). The diurnal changes were very slight, neutrophils decreased while lymphocytes increased at 14:00 $\mathrm{h}$ than at 08:00 $\mathrm{h}$. The percentage of eosinophils was higher and that of lymphocytes was lower in sucklings than in weanlings as reported by Ashour et al. (1998). Holman (1956) reported that the lymphocyte (\%) in calves and heifers was $33 \%$ at the day of birth and then increased rapidly to about $71 \%$ at the third month. The increase in eosinophils with the advance of age has been recorded by Holman (1956) and Greatorex (1957). Few basophils were observed in both winter and summer (Table 3). Holman (1956) reported that basophils increased in number at about 6 months of age and then was maintained at a level of about $0.7 \%$. The monocytes percentages showed great augmentation in summer to increase, in average, by $50-60 \%$ of the value in winter (4.4 vs. 2.8), but showed a clear diurnal stability all the day in both seasons. This increase in monocytes is a clear sign of stress.

\section{Thyroid hormones}

Plasma $T_{4}$ levels were slightly higher under high environmental temperature (IAT plus temperatures of housing elements) as shown by the higher values in summer than in winter and in afternoon than in morning values in both seasons (Table 3). The seasonal changes were greater than the diurnal changes. These seasonal and diurnal changes in $T_{4}$ concentrations due to high environmental temperature ranged between 0.4 to $0.6 \mu \mathrm{g} / \mathrm{dl}$ and between 0.1 to $0.3 \mu \mathrm{g} / \mathrm{dl}$, respectively. These results are in agreement with those of Collier et al. (1982) and Mohamed (1984). The last author showed a significant increase in $\mathrm{T}_{4}$ in animals exposed to $30^{\circ} \mathrm{C}$ than animals exposed to $20^{\circ} \mathrm{C}$.

There were seasonal changes in $T_{3}$ concentration causing reductions in summer of 1.3 and $9.7 \mathrm{ng} / \mathrm{dl}$ at $08.00 \mathrm{~h}$ and $14.00 \mathrm{~h}$, respectively. The diumal changes indicated an increase by 14.4 and $6.0 \mathrm{ng} / \mathrm{dl}$ at $14: 00 \mathrm{~h}$ than those at 08:00 $\mathrm{h}$ in winter and summer, respectively (Table 3). 
Ashour et al.

The conversion of $T_{4}$ to $T_{3}$ seems to has been slowly in summer than winter as indicated by the higher $T_{4} / T_{3}$ ratio in the summer season (Table 3 ). The thyroid index $\left(\mathrm{T}_{4} / \mathrm{T}_{3}\right.$ ratio) was lower at afternoon than in the morning in both seasons. The $T_{3}$ is some $3-5$ times more active than $T_{4}$ and about $30 \%$ of daily $T_{4}$ production is diverted to produce $80 \%$ of daily $T_{3}$ hormone (Reece, 1991).

it could be concluded that the roof characteristics of a closed stable have clear effect on all the physiological responses of suckling calves especially RR (Table 3) which is considered the best indicator of heat stress or heat tolerance. Anyhow such asbestos roofed stable is characterized by a wider diurnal rhythm, in differences of the temperatures of its components (roof, walls and internal air) at the highest level (12:00 and 15:00 hs) and the lowest level $(06: 00 \mathrm{~h}$ or 22:00 h). It could be suggested that the colder walls and roof at night (22:00h) and early morning (06:00h) act as heat sinks as stated by Esmay (1976) based on experimentally studied sinks. Such heat sinks facilitate heat dissipation periodically through radiative heat transportation from the animal body, thus relieving the animal from the excess of stored body heat during the hot midday time. Animals had better comfort conditions during these times (06:00h and 22:00h) especially in summer as evidenced by lower RT and RR, while they increased greatly at the midday time which is considered a sign of distress.

The concept of heat sinks needs further studies and consideration of the thermal properties of the building. Attempts of heat stress alleviation must be taken in consideration, especially that most calf houses in Egypt are similar to that in the present study. This preliminary study in already established stable call for further studies in housing models with different designs and materials to find out the best model under the prevailing climatic conditions in different areas in Egypt.

\section{REFERENCES}

Ashour, G., 1990. Water balance in bovines as related to heat regulation. Ph. D. Thesis, Fac. Agric., Cairo Univ., Egypt.

Ashour, G., S.A. Fawzy, E.A. Omar and M.S. Sayah, 1998. Physiological reactions of weaned Friesian calves in different housing types. Egyptian J. Anim. Prod., Supplement Issue, Dec. 1998 (In press).

Badreldin, A. L.; M.M. Oloufa, A.A. Asker and M.A. Abdel-Ghany, 1951. Effects of seasonal variations on body temperature, respiration rate and pulse rate of cattle and buffaloes. Fac. Agric. Bull., 4 : 3, Cairo Univ., Egypt.

Charles, D.R., 1981. Practical ventilation and temperature control for poultry. In: Environmental Aspects of Housing for Animal Production. J.A. Clark (ed.), Butterworths, London, p. 183. 
Clark, J.A. and K.M.Cena, 1981. Monitoring the house environment. In: Environmental Aspects of Housing for Animal Production. J.A. Clark (ed.), Butterworths, London, p. 309.

Clark, J.A. and A.J. McArthur, 1994. Thermal exchanges. In: Livestock Housing.C.M. Wathes and D.R. Charles (eds.). CAB International, UK, p. 97.

Collier, R. J.; S.G. Doelger, H.H. Head, W.W. Thatcher and G.J. Wicox, 1982. Effect of heat stress during pregnancy on maternal hormone concentration, calf birth weight and postpartum milk yield of Holstein cows. J. Anim. Sci., $54: 309$

Duncan, N.B., 1955. Multiple range and multiple F test. Biometrics, 11: 142.

Esmay, M.L., 1976. Principles of Animal Environment. AVI Publishing Company, Inc., Westport, U.S.A.

Greatorex, J.C., 1957. Observation on the haematology of calves and various breeds of adult dairy cattle. Brit. Vet. J., 113: 469 .

Hahn, G.L., 1985. Management and housing of farm animals in hot environment. In: Stress Physiology in Livestock. M.K. Yousef (ed.) CRC, Inc. Boca Raton, Florida, USA, p. 151.

Hoiman, H. H., 1956. Changes associated with age in the blood picture of calves and heifers. Brit. Vet. J., $112: 91$.

Kobeisy, M.A., 1983. Adaptation of Friesian cattle in Upper Egypt. M. Sc. Thesis, Fac, Agric., Assiut Univ., Egypt.

Kotby, E.A., A.K.I. Abdel-Elmoty and M.A.A. El-Barody, 1987. Physiological responses of Friesian cows kept under asbestos and linen textile sheds. Minia J. Agric. Res. and Rev., 9: 1237.

Lawrence, N.G., 1994. Beef cattle housing. In: Livestock Housing. C.M. Wathes and D.R. Charles (eds). CAB International, UK, p. 339.

Milne, R.J., 1983. Warm housing for dairy calves. Dairy Housing II. Proc. of the Second National Dairy Housing Conf., March 14- 16, Madison, Wisconsin, American Society of Agricultural Engineers (ASAE), U.S.A.

Mohamed, A.A., 1984. Some physiological responses of pregnant cows exposed to heat stress. Indian J. Anim. Sci., 54 : 1072.

Reece, W.O., 1991. Physiology of Domestic Animals. Lea and Febiger, Philadelphia, U.S.A.

SAS, 1990. SAS user's guide, statistics, SAS Inst. Inc., Cary, North California, USA.

Sendecor, G.W., 1982. Statistical Methods. 7th Ed. Aiwa State College Press. Ames, Aiwa, USA.

Shafie, M. M. and L.M.M. El-Sheikh Aly, 1970. Heat tolerance of Friesian cattle under Egyptian climatic conditions. Egyptian J. Anim. Prod., 10 : 99.

Shafie, M.M. and A.L. Badreldin, 1966. Skin temperature and temperature gradients in bovines. Proc. 2nd Anim. Prod. Conf., Cairo, Egypt, March 310, 1963, P. 375. 
Webster, A.J.F., 1981. Optimal housing criteria for ruminants. In: Environmental Aspects of Housing for Animal Production., J.A. Clark (ed.), Butterworths, London.

Webster, A.J.F., 1984. Environmental needs. In: Calf.Husbandry, Health and Welfare. Webster, A. J. F. (ed), Granada Publishing Ltd., London.

Zenhom, M. and H.A. Daghash, 1994. Temperature gradients of Jersey cows in Upper Egypt. Egyptian J. Anim. Prod., 31: 333, Supplement Issue, Nov. (1994). 
تأثير الخصائص الطبيعية للإسكان على الأثلاء الفقيولوجى لعجول الفريزيان الرضيعة جمال عاشور '، محمد محمود الثشافيى'، سهبيز فوزى"، محمود سبد صبياح'

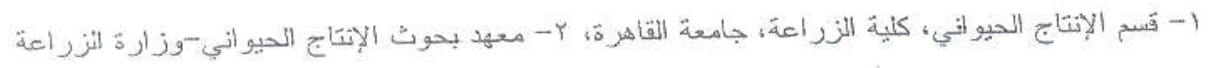

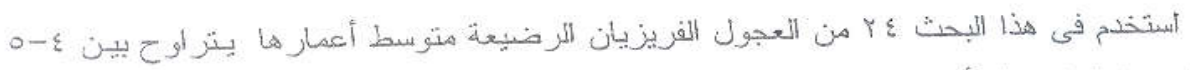

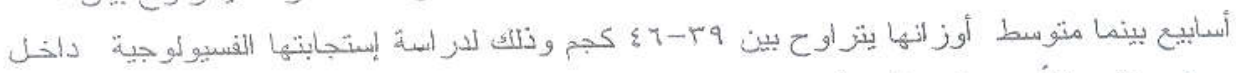

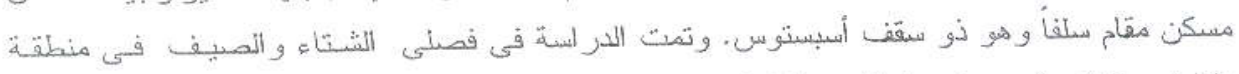

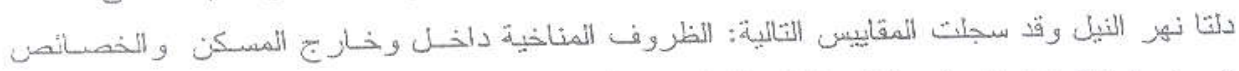

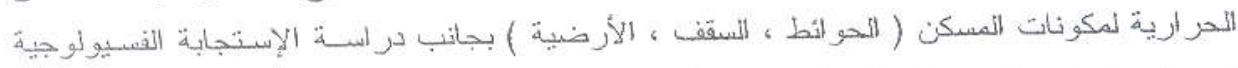

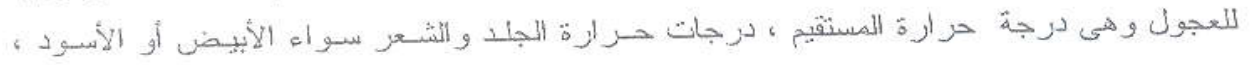

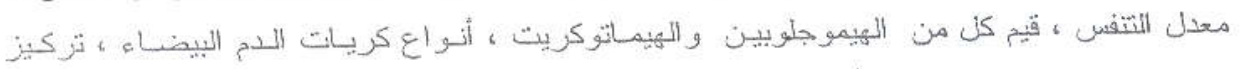

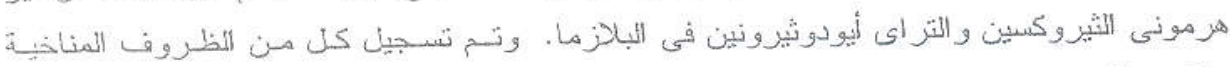

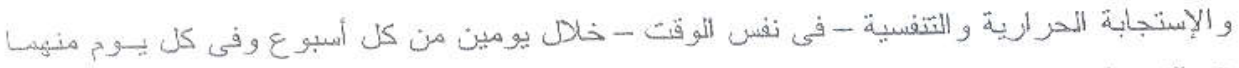

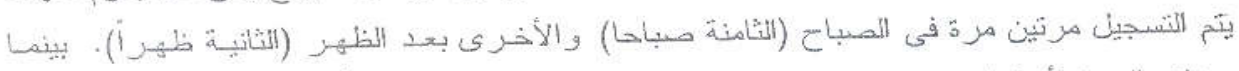

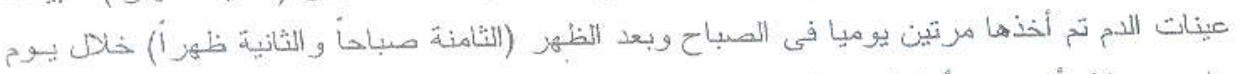

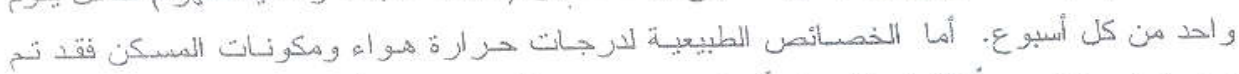

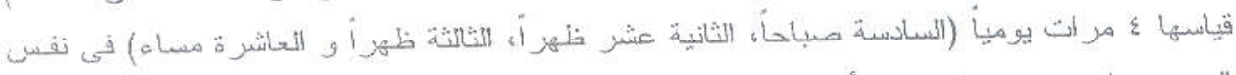

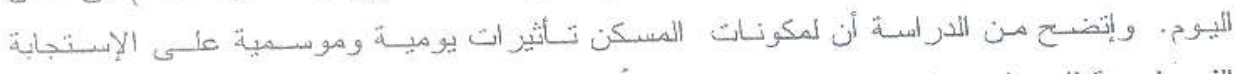

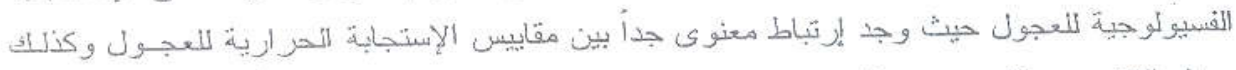

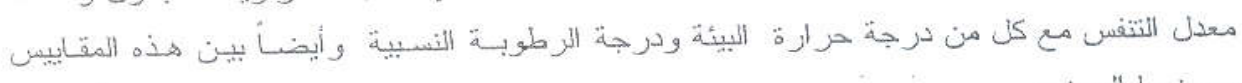
وبحضنها الثبعن

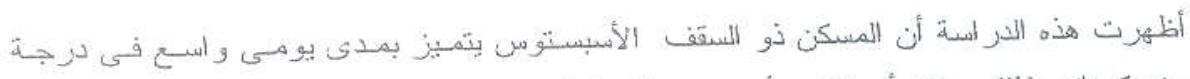

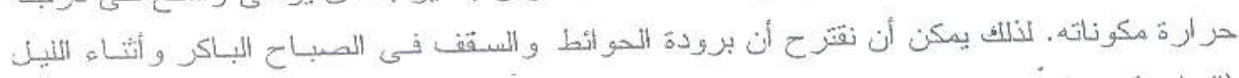

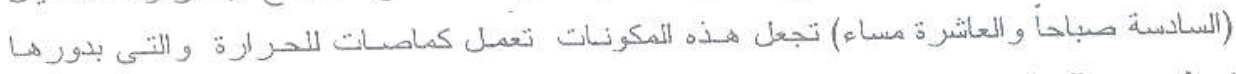

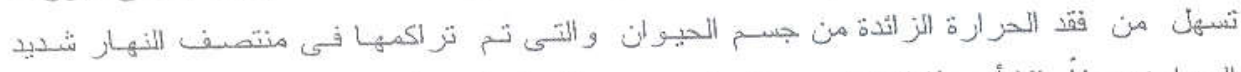

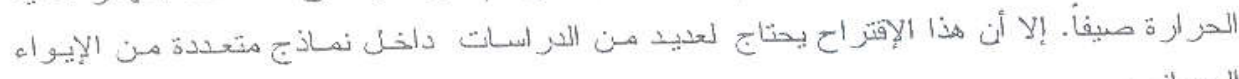
الاحيو النى 